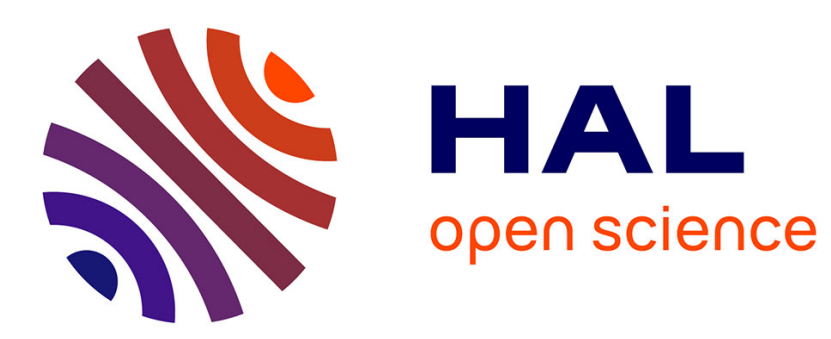

\title{
The boundaries of unemployment. Institutional rules and real-life experiences
}

\author{
Didier Demazière
}

\section{To cite this version:}

Didier Demazière. The boundaries of unemployment. Institutional rules and real-life experiences. The deconstruction of unemployment as a political question: employment as a floating signifier, 2018. hal-03552357

\section{HAL Id: hal-03552357 \\ https://cnrs.hal.science/hal-03552357}

Submitted on 2 Feb 2022

HAL is a multi-disciplinary open access archive for the deposit and dissemination of scientific research documents, whether they are published or not. The documents may come from teaching and research institutions in France or abroad, or from public or private research centers.
L'archive ouverte pluridisciplinaire HAL, est destinée au dépôt et à la diffusion de documents scientifiques de niveau recherche, publiés ou non, émanant des établissements d'enseignement et de recherche français ou étrangers, des laboratoires publics ou privés. 
The boundaries of unemployment

Institutional rules and real-life experiences

\section{Didier Demazière}

Any definition of unemployment spurs debates on the issue of measurement: precisely how many unemployed are there, who should be considered unemployed and what criteria apply? This leads to discussions on how to measure unemployment: some ask how do we quantify unemployment according to the source, with particular regard to survey and administrative data (Lemoine, 2007); others point out that the figures depend on which indicators are used, calling for a diversification of the instruments used to measure unemployment (Castel et al., 1997); while others still warn that the scope of international harmonisation is limited if specific national and institutional features are not taken into account (Desrosières, 2003). It is now accepted that there is "no "correct" figure for the number of unemployed; on the contrary, there are as many statistics as there are sources and ways of conventionally - not arbitrarily - defining unemployment' (Marchand, 1991, p. 8). Therefore, this is not just a matter of statistics but of the very definition of unemployment: what is to be understood by the term; is there any consensus on the category of unemployed; where should the line be drawn between unemployed and not unemployed; who decides who is to be called unemployed; and who has authority over the different meanings?

Where do the boundaries of unemployment lie and what characterises them: is it clarity, sharpness, stability, obviousness, finesse and precision or, on the contrary, is it obscurity, ambiguity, instability, fragility, density and approximation? Tracing a border consists in making a separation and a distinction within the context of continuity. It is a social and political act, because it creates classifications that may then shape the functioning of groups and societies (Durkheim and Mauss, 1903). Unemployment is also one of those operative categories (Demazière, 2003) that are both shared representations of the social universe and resources for taking action in and on that universe. That being so, who are the actors capable of mobilising the categories for action, and who is able to modify and adjust the scope of that action? In formulating such questions, the analysis is oriented towards the work involved in producing boundaries (Gieryn, 1983; Evans, 2009). Our hypothesis is that, in the case of unemployment, working on boundaries - taking them into account even while modifying or displacing them - is an activity carried out by institutional stakeholders who define the rules for managing the unemployed, as well as by those who actually experience joblessness. 
Therefore, the boundaries - of this category - are not limits drawn by experts, taken to be self-evident and immutable. Boundaries cause phenomena to emerge and to become visible, and boundaries redesign and recompose them when they have been displaced (Degenne, 2005). Those phenomena do not pre-exist the boundaries, rather it is the boundaries that make them materialise: 'we should not look for boundaries of things but for things of boundaries' (Abbott, 1995, p. 857). Boundaries are thus where definitions are worked out, a fact that was masterfully demonstrated with regard to emerging unemployment at the turn of the 20th century: unemployment is not the reflection of an existing social reality, nor even the realisation of an emerging reality, it is an invention involving a great number of actors (Salais et al., 1986; Topalov, 1994). Initially, the notion of boundary allowed us to consider social or ethnic groups not as objective and substantial entities but as the historical and conventional result of demarcation (Barth, 1969). Over time, the concept gradually separated itself from the notions of group or territory (Silber, 1995; Jeanpierre, 2010) and spread to other collective or symbolic bodies. The reasoning remains constant: it is relational because differences are always produced with reference to another whose identity is reinforced by the tracing of the boundary. It is a process, because differences are always the temporary crystallisation of entities whose relationships change. Boundaries thus imply working on the relationships and processes that define them.

The aim of this chapter is to propose an analysis of contemporary unemployment by describing the movements of its boundaries: its boundaries with employment because it emerges historically on the negative side of salaried employment, and its boundaries with inactivity because it has been differentiated from poverty and idleness. To explore how the boundaries of unemployment function, we will focus here mainly on two aspects: public action - since unemployment is a codified status - and the persons concerned - given that unemployment is a subjective experience. Two types of boundaries correspond to these two aspects. In the first case, the boundaries are institutional: they define various status-bound situations and regulate the access to material resources (benefits, public employment services) or immaterial resources (recognition by the public employment service). In the second case, the boundaries are 'symbolic' (Lamont and Fournier, 1992; Lamont, 2001): they influence the meanings attributed to personal experience (of unemployment but also atypical forms of employment and work) and affect categories of identification (affiliation, identity claims) and future projections (accessible, valued positions). We will analyse each of these two aspects in turn and attempt to show that boundary work is heterogeneous both in its orientations and in its consequences. 


\section{Institutional status boundaries}

Unemployment is not an economic issue comparable to balancing the supply and demand percentage of employment. Moreover, 'in a purely commercial world, unemployment does not exist' (Eymard-Duvernay, 2001, p. 292). Unemployment is defined by institutional boundaries that disconnect it from other social positions involving activity or inactivity. To see how these boundaries have developed, we will focus on the rules governing unemployment coverage and the distribution of replacement incomes, for they are at the heart of the categorisation process.

\subsection{Codified boundaries: unemployment is employment}

\section{Sifting out the poor}

Historically, joblessness is the result of new ways of considering the poor and of a stabilised partition delimiting three groups, each associated with a specific approach (Castel, 1995): the infamous 'idle poor' who must not be helped but, on the contrary, suppressed, locked up and forced to work; those unfit to work, marked by an infirmity or other handicap, who must be afforded minimal assistance, though with no hope of their returning to work; and the involuntary poor who are physically fit, searching for ways to survive, and who must be helped and assisted in their quest. At the start of the 20th century, the invention of unemployment spurred the establishment of relief organisations initiated by workers or municipalities, subsequently taken over by the State. Very early on, the benefits allocated were matched to the job search which - before the role of the intermediary became more widespread - targeted specific occupations (Luciani, 1990; de Larquier, 2000). This response to the financial precariousness generated by the scarcity of jobs traced a border between those workers who had fallen victim to a bad economic situation and the poor, considered unemployable or lazy, thus between the good and the bad jobless (Topalov, 1987), between the unemployed and the inactive. In that sense, the meaning of unemployment has evolved considerably: "seen as a catastrophe today, being called "unemployed" at the turn of the century meant an enhanced social image' (Mansfield et al., 1994, p. 16).

Inventing unemployment was intended to improve production by stimulating the factors that constitute it - here, the labour factor - with the aim of producing more wealth (Gautié, 2002). It signified organising the labour market, controlling the employment relationship and disciplining workers' behaviour. For, in the industrial economies of the late 19th century, workers were still marked by discontinuity, fragmentation, irregularity and unpredictability: 
in rural areas, many workers still farmed and worked in the fields when the season required it, while in the towns, people changed jobs frequently because of poor working conditions or salaries. Against this background, replacing a service contract by an employment contract rendered the relationship of subordination official in the long term and strengthened the tie between worker and employer. Over the decades, that legal development has spread and evolved with the result that unemployment is now anchored to salaried employment as its complement, its corollary, 'its negative face, but also its raison d'être' (Lefresne, 2008, p. 3).

\section{Identifying the potential workforce}

However, although the unemployed are potentially wage earners, what are the criteria for identifying them, and what principles apply when setting up their benefits or accompanying them on the road to employment? The main criterion is the involuntary nature of being jobless. Once this is established, we must then focus on verifying the authenticity of that involuntary quality, which is no easy task. The first criterion to be applied for such verification was a person's work history. For instance, in 1895, the French Supreme Labour Council (Conseil Supérieur du Travail, the Ministry of Labour at that time) defined unemployment as 'the situation of a worker who usually makes his living in a specific occupation but is presently out of work in that profession' (Daniel and Tuschzirer, 1999, p. 44). Unemployment signified 'professional unemployment', and the fact that a person exerted a professional activity regularly was taken to indicate that he was forcibly and undeservedly being deprived of work. That sort of logic still underpins the activities of employment agencies, which refuse to help or present job offers to casual workers who are perceived as lacking in both discipline and merit - also known as the 'sham unemployed' (Marpsat, 1984).

In the second half of the 20th century, the will to work was disassociated from a person's work history and linked instead to the job search. As of the 1960s, when the International Labour Office made the will to work an essential criterion, that approach became standard: any person over the age of 15 with no waged or unwaged employment, actively looking for a job and immediately available was considered unemployed. That definition enlarged the scope of unemployment, since a simple job application was enough to be officially recognised as unemployed. However, the positive side of the status of unemployment was only temporary, partial and conditional: temporary because the application had to be renewed on a regular basis and because the job search was monitored, which might have led to loss of the status; partial, since the acknowledgement of a job application did not automatically make a 
person eligible for benefits; and conditional, since each individual claim to the status of unemployed depended on social and regulatory conditions - such as being considered as legitimately occupying that status from a gender point of view (Maruani, 2002) - and also depended on the use of the resources made available as a result of that status (Marchand and Thélot, 1983).

It should be added that not all population groups are equally entitled or prepared to enter the world of unemployment. If one considers a large spectrum of countries - Europe and the United States - three lines of reasoning emerge concerning the distribution of resources which, when taken together, point to 'national activity and employment systems' (Barbier and Gautié, 1998): first, resources may consist of participation-based production (wage labour, employment); second, they may be linked to the redistribution of social transfers (replacement incomes); or third, they may be associated with interpersonal relationships in the private sphere (family solidarities). The category of unemployment was invented so as to isolate those who are involuntarily excluded from the primary resource base, i.e. employment. To understand that boundary, one must take any related categories into account. However, in many Western countries, the second two lines of reasoning concern mainly women, who are encouraged in many ways not to enter the labour market - pro-family policies, the sexual division of household labour, social norms governing the distribution of jobs - or to leave it when they are laid off (Maruani, 1996). During the period known as the Economic Miracle (Les Trente Glorieuses), a time when the scope of unemployment was consistent and very clearly delineated, those boundaries had selective effects to the detriment of women (but also to the detriment of individuals at both extremes of the working life cycle). If unemployment is the opposite of employment, it concerns the breadwinner first and foremost. In the period following this, a structural surplus of manpower caused employment - in different ways depending on the country - to undergo significant transformations; the realm of unemployment shrank considerably, while the volume of joblessness continued to grow.

\subsection{Reinforced boundaries: shrinking unemployment}

\section{Indemnifying unemployment}

The erosion of employment standards and the growing 'precariousness of the labour contract' (Ghesquière, 2014) are powerful trends in Western societies. They take different forms depending on national trajectories (Lefresne, 2005), but atypical forms of work - compared to the Fordist model of wage employment - crop up everywhere: short-term contracts, part-time or segmented work, service contracts, multiple employer contracts, subleasing of employees, 
independent entrepreneurs working for a single contractor, solo work and even work in the informal labour market. All these developments have an impact on the institutional boundaries of unemployment.

Since the 1990s in Europe, public deficits, a reduction in statutory contributions and a restructuring of welfare systems, have made access to unemployment benefits more difficult (Freyssinet, 1998). The pace and magnitude of reforms differ, as do their justification and implementation, but a certain number of shared key orientations can be observed (Clasen and Clegg, 2006). The criteria for eligibility have become more stringent, and consequently the area covered by unemployment insurance has shrunk. Of course, coverage rates vary from one country to another, but in all countries, the length of time a worker must pay into the plan - i.e. the number of months' payment required for a given period of reference - has been extended. Allowances are becoming smaller, and the replacement rate based on the last salary received is diminishing (in Europe, it varies between $30 \%$ and $80 \%$ during the first six months of unemployment). Despite differences between countries in minima and maxima, or in the conditions sometimes placed on access to benefits (income level, family status, etc.), the trend remains the same. The length of time a worker can be in receipt of compensation is becoming distinctly shorter as well, even though the permitted maximum length can vary considerably (from six months to five years). Overall, changes in patterns of employment and increasing transitions between employment and unemployment have had the effect of reducing the cumulative benefits and subsequently shortening the periods during which allowances are paid. This is still the case regardless of changes in legislation, except in a few countries where the duration of benefits is not dependent on the length of time that contributions have been made (Denmark, Italy, United Kingdom).

A second feature common to Western countries is the tighter checks carried out on the jobless, all the more salient in the light of simultaneously evolving social representations, making joblessness and its duration a matter of individual responsibility. There is a strong tendency towards that 'rigorous turn' (Dubois, 2007) in European policies, which promote and support closer supervision of the unemployed, especially those who are in receipt of benefits. In all areas, the link between allowances and supervision is becoming stronger, although activation standards - a dubious, prescriptive term, since benefits are considered passive expenditure, thus ipso facto obligatory - fluctuate between two, variously attractive poles depending on the country. On the one hand, allowances are seen as discouraging people from looking for work; benefits should therefore be kept to a minimum and beneficiaries monitored so as to speed up the process of finding a job. On the other hand, allowances are 
seen as a resource that provides access to employment, so the amount and duration should be adequate regardless of the fact that the individual's earnestness in their search for a job must be verified. Variously combined, these two lines of reasoning have brought about an ideological transformation in European countries (Serrano Pascual, 2007) in support of activation policies that have given rise to a wide variety of interpretations (Barbier, 2009). It can at least be observed that more stringent follow-up of unemployed in receipt of benefits is in place (constrained by institutional limits), as well as closer supervision of the job search, and that the notion of an adequate and reasonable job offer places greater demands on the unemployed. The procedure involving the signing of a contract by the individual and the public employment service is widely used (Willmann, 2001), facilitating checks and, in particular, penalties; the obligations stated in the terms of such a contract do not cover the job search but concern specific points that are deemed better tailored to individual circumstances and are accepted by the unemployed person (salary level, percentage of working time, distance from residence to place of work, etc.).

\section{Alternative systems of coverage}

All these changes whittle the perimeter of unemployment down to the criteria that obtained when the category was first conceived: an allowance directly dependent on a person's work history and its duration, and the job search, subject to tighter checks. Consequently, unemployed persons whose work history is deemed lacking and who are not sufficiently active in their search for a job risk being driven to the margins of unemployment or even beyond its institutional boundaries. In these times of persisting instability in terms of employment and unemployment, boundaries have shifted and begun to oscillate between benefits and other systems of social protection that define the status of inactivity. Moreover, inactive persons are widely called upon to substitute for the jobless or to fill positions that make it possible to reclassify individuals who were initially recognised as unemployed. That trend takes specific forms in different countries, depending on the status they wish to emphasise.

Early retirement packages have been widely implemented as part of workforce reduction plans in order to prevent older laid-off employees from being classified as unemployed (Palier, 2003). Despite injunctions from Brussels aimed at raising seniors' employment rate, these systems persist, and, most importantly, there is little likelihood that those affected would be able to move from unemployment to employment, given that they are provided with easier access to benefits or are exempted from looking for work. In this way, many seniors find 
themselves in a hazy, peripheral area of unemployment, on the fringes of inactivity (Demazière, 2002). In some countries, occupational incapacity and invalidity systems are often used to regulate patterns of activity and reduce the number of long-term unemployed. In the Netherlands, for instance, there is widespread social support for the implementation of extensive early retirement programmes - in the 2000s, those individuals in receipt of an invalidity pension were three times more numerous than the registered unemployed (Wierink, 2002). In the United Kingdom, in line with the dominant logic of activation, those entitled to invalidity benefit and declared apt receive reduced allowances (Angeloff, 2011). Admittedly, transfer policies promoting a shift from unemployment to assistance schemes, aimed at the least employable unemployed, became less popular during the 1990s. However, other movements lead many unemployed persons to various ill-defined situations of inactivity. This concerns, first and foremost, those who are unable to escape the condition of being unemployed: for example the 'discouraged unemployed', who wish to work but do not search for jobs and are therefore classified as inactive; or those vulnerable and disoriented young people whom the European Commission labels as NEETs (Eurofound, 2012); or even lone mothers who are targeted by redistributive policies (specific income support or allowance for the education of children) that encourage their inactivity (Demazière, 2017).

Such policies of transferring those unemployed deemed to be the least employable towards specific assistance systems - which may also include social protection such as that provided by the minimum wage - displace individuals from one social status to another and are instrumental in redistributing their identities. However, in the $2000 \mathrm{~s}$, the obligation to search for a job began to extend beyond the boundaries of unemployment, placing an increasingly heavier burden on social minima recipients. This does not, however, suggest a reversal of flows at the boundaries of unemployment, since this extension concerns the obligations associated with unemployment status but not entitlements such as unemployment benefit or career guidance. More and more inactive people are thus subject to obligations associated with unemployment but without being fully established as having this status. Therefore, the dissemination of job-search standards does not open up the boundaries of unemployment.

The difficulty in eradicating unemployment through inactivity is compounded by systems where the relationship between employment and unemployment encourages or forces a person to accept any job, even an undesirable one (Huyghues-Despointes, 2001). Legal mechanisms vary, with some transferring a portion of the benefits to any employer who takes on an unemployed person, who in turn continues to receive a fraction of his entitlements on condition that he accepts a low-paid job. As a result of these public policy systems, the active 
- or 'activated' - unemployed person is facing a new and somewhat paradoxical situation: on the one hand, the person is nearing employment, even if it means taking a less than desirable job; on the other hand, he remains aloof for fear of falling into the 'trap of precarious employment' or temporary work that such systems entail (Lefresne and Tuchszirer, 2001).

In a context marked by the tendency towards activation common to many countries - albeit to varying degrees - the institutional boundaries of unemployment shift. Whether or not a person is unemployed (or acknowledged as such) hinges increasingly on how close they are to employment, which is assessed on multiple levels: the intensity of the job search, the likelihood of securing a job, the identification of factors that might prolong the period of unemployment, the existence of possible stigmas (age, health issues), etc. Implementing these selective and discriminating criteria causes the realm of unemployment to shrink. The unemployed themselves play hardly any role in this: they do not participate in defining the rules or the systems, and they have very little leeway in applying them to their own personal situation. Nevertheless, the boundaries of unemployment are not only institutional and do not boil down to being merely instruments for managing statuses and a means of assigning people to those statuses: they also shape the actual, real-life experiences of unemployment which in turn modify and reconfigure those boundaries.

\section{The symbolic boundaries of an experience}

Unemployment is not only a status contained within institutional boundaries, it is also an experience that is lived through subjectively (Demazière, 2006). The ways one considers one's social situation or interprets events that occur (and behaves in consequence) also define the boundaries of unemployment - its symbolic boundaries, which determine feelings of belonging and identity. Experiencing unemployment raises questions about how one relates to employment, determines how the status is perceived and furthers the process of interpreting work as a goal that is achievable by the unemployed. In order to grasp the ways these boundaries move, it is necessary to adopt a comprehensive approach that focuses on an understanding of what it means to be unemployed.

\subsection{Moving boundaries: is unemployment employment or work?}

\section{The essential place of employment and the job search}

The job search occupies a crucial place in the experience of unemployment because it is perceived as the counterpart of a person's right to financial assistance: it is 'where the unemployed person's legal identity is most securely anchored' (Willmann, 1998, p. 248). 
Recent research based on approx. 60 biographical interviews with persons officially unemployed in France confirms this (Demazière et al., 2015). ${ }^{1}$ It represents a salient trait in the condition of being unemployed: given that unemployment is a state of deprivation, it is oriented towards employment. A significant amount of research shows that the daily life of an unemployed person revolves to a certain extent around employment in its various forms, involving, on the one hand, strong personal commitment and active use of networking, and, on the other, discouragement and withdrawal (Bakke, 1940; Schnapper, 1981; Bartell and Bartell, 1985; Gallie and Vogler, 1994). Efforts to make sense of unemployment are not intended to be inward-looking but are aimed at producing different outlooks, coming up with ways out of overcoming obstacles or developing alternatives, and, in order to give these perspectives credit and substance, they also devise rapid responses and experiment with different solutions. Unemployment seeks to eradicate itself, an obliteration that can be perceived as being far-off or immediate, probable or uncertain, total or partial.

However, the erosion of contractual standards has had a particular impact on jobs, which have changed considerably over the past few decades. The unemployed person who seeks access to work or applies for a job is the most exposed to atypical contracts. For the unemployed, employment is a moving target, uncertain or remote. The person becomes caught up in the flow of life, buffeted by the hopes or disillusions that are triggered by the steps they have taken to find work and by their share of failure. Employment explodes into a myriad of situations, all more or less plausible, acceptable, desirable or accessible, all converging towards a vanishing point. And experiencing unemployment, as related by the interviewees, consists in evaluating interpretations and finding solutions to an undervalued and humiliating condition. But employment is too narrow a concept to account for the variety of prospects envisaged by jobseekers. A larger entity is at stake, as indicated by the expressions used: 'work; something to do; anything; a permanent contract; even moonlighting; just to be able to eat; a project; money; to be employed; even undeclared would be all right; I dream of setting up my own business; an odd job; a real job; earn a living; stay in my profession; just put me somewhere; a salary, that's all I ask'.

\footnotetext{
${ }^{1}$ The aim was to ask interviewees to explain what was their experience of unemployment and to relate the events that had occurred during that period, how they interpret them, their endeavours to remain resilient as well as their understanding of what it means to be unemployed. Interviews were conducted according to a semi-directive method (without a grid), each one lasting from 1 hour to 2 hours 40 minutes; at the time of the interviews, 57 people were registered with the French National Employment Agency (Pôle Emploi). The sample was built with a view to demonstrating a diversity of situations, and was controlled by duration of unemployment, age and level of education.
} 
This sample of expressions gathered during the interviews illustrates the broad spectrum of outlooks. Rather than employment per se, they relate to activities that are both sources of income and a support for some sort of status - not in the legal sense of the word but in the sense of conferring a social existence and an identity - what we call accessible work. Thus, when real-life experiences are taken into consideration, unemployment does not boil down to being the opposite of employment - or to the act of looking for employment - it is reshaped in a process of reinterpreting work as an achievable goal for the unemployed. The issue is not about being more or less attached to work or having a greater or lesser will to work; it is about the conceptions of work itself, and therefore of unemployment.

\section{Accessible work in its different forms}

An analysis of the interviews made it possible to identify four contrasting conceptions of work, all related to unemployment - points of view that condense specific conceptions that we have summed up according to the place, the contract, the project and 'bricolage'.

The first way in which accessible work (the place) is conceived is defined by the statutory conditions imposed by social protection. Certain specific jobs represent safe places to work where one is lastingly protected from unemployment, serving as a fortress, an impregnable citadel. The full-time permanent contract (CDI) is the legal translation of that form of accessible work, though the expressions used are more diverse ('real work', vrai travail; 'safe job', emploi sûr; 'a place for you', une place où tu es collé; 'security', sécurité; etc.). The experience of unemployment is structured around the job search, and unemployment is interpreted according to its official definition. Employment is given a restrictive meaning, which indicates that being employed remains the norm and is the focal point in a person's aspirations. However, an assessment of the likelihood of securing that place was expressed in a variety of ways. Some respondents were confident, backing themselves up with the argument that they were carrying out an active and proficient job search. Others simply expressed their preference for one of several possible outcomes. Still others mentioned the obstacles and constraints that reduce the possibilities of securing a place. For many of them, that place seems out of reach, and so the notion of accessible work must be readjusted.

Accessible work is also defined by various statuses that denote participation in production, a participation that is governed by official rules and regulations. This leads us to apply the term 'contract' to such a perspective, even if not all are backed up by a labour contract in the strict sense of the term, i.e. short or fixed-term contracts (CDD), interim contract work, integration or state-assisted contracts, internships, industrial training, one-off contracts, etc. Although 
these are not all considered to offer the same level of reward or security, they are all considered possibilities for finding one's way out of the unemployment tunnel. The projections take on different meanings, depending on whether they are experienced as temporary or as controlled arrangements, as an acknowledgement of one's entourage and the institutions that advise seizing upon the tiniest opportunity, or endured as the only possibility to counter the relatively serious risk of finding oneself in limbo. A contract is a marker that blurs the boundaries of unemployment, because it may mean exiting unemployment or, on the contrary, being trapped in unemployment disguised as work. Unemployment brings to bear a pressure that enlarges the definition of salaried employee and slackens the norms defining work.

Accessible work can be consolidated by promoting a specific activity that can be used to visualise the future - a craft (métier); a passion; a qualification; skills (compétences); 'doing something with your hands' (quelque chose dans les mains), etc. We called this approach 'the project' in order to designate a work objective and indicate the series of preparatory tasks that would allow the person to advance in that direction: tests, training periods, one-off jobs, occasionally unpaid or even informal work. The project directs the person towards the margins of salaried employment: often fragile forms of working alone (such as selfemployment, carrying out autonomous tasks, sub-contracting for a one-time employer, becoming an independent actor or artist, freelancer or freelance journalist), less often the classical forms of independent labour (such as setting up one's own business, creating a company or forming a partnership in a small firm). Such projects are very ambivalent. In some cases, the rewards associated with the work are good enough to erase the stress of unemployment. In other cases, the prospect of a self-fulfilling activity is hazy and unsure, or even fades into a vague dream that fails to eliminate unemployment. In still other cases, the person is not very enthusiastic about his project because it is seen as nothing more than a last resort after other possibilities have fallen through, or because it hinges on forms of employment that are considered degrading or worthless. Typically, the project alters the opposition between the status of jobless and that of employed worker.

Finally, accessible work may also signify informal or unofficial activities that confer recognition, meaning and financial resources: 'I make do' (je me débrouille); 'it's not declared' (c'est pas declaré); 'only a couple days' work' (quelques chantiers); 'lending a hand' (des coups de mains); 'we help each other' (on s'entraide), etc. As in the above examples, the forms it takes vary in terms of amplitude, regularity, stability, profitability and legitimacy. However, it represents actual practice rather than a projection into the future, 
which is why we call it 'bricolage'. The meanings of these activities also vary: they may indicate a discreet sort of resourcefulness ('making do') that relies on a well-stuffed address book; or they may indicate a weak capacity to act that relies on family and friends and leads to becoming dependent; they may also reflect a way of life based on expediency, despite personal efforts to avoid the risk of exclusion. For a number of unemployed, such bricolages are fragile and not very far-reaching, but they determine their attitudes towards work and orient their future towards relatively informal activities. Given that unemployment and work seem so closely associated as to be almost blended into one another - only the importance attributed to the chosen activity may allow the use of one or the other term in order to qualify a given situation - bricolage dilutes the boundaries of unemployment.

An analysis of experiences of unemployment in France shows that the relationship between unemployment and employment, traditionally complementary due to the institutional codification of social statuses, has deteriorated. This degradation amounts to more than a reduction in occupational claims and aspirations in terms of wages, employment status, working time, etc. It goes far beyond these declining expectations that are already well observed (Schnapper, 1981; Bartell and Bartell, 1985; Gallie and Vogler, 1994), as it tends to replace the targeted job (even a degraded one) by more imprecise activities that, despite being informal and having no status, are deemed to be 'accessible work'. It reveals how employment - as a goal for the future - has broken down into countless interpretations of accessible work. That diversity translates a certain vagueness surrounding the symbolic boundaries of the experience of unemployment and shows how they differ from the institutional boundaries.

\subsection{Fuzzy boundaries: unemployment is vulnerable}

International comparisons confirm that the fragility of unemployment and the haziness of its boundaries are not seen only in France, as illustrated by a survey carried out among 199 individuals in situations of unemployment (administratively speaking) in three metropolitan areas - Paris, Sao Paulo and Tokyo (Demazière et al., 2013). ${ }^{2}$ In this survey, the

\footnotetext{
2 The biographical interviews aimed to gather narratives of experience in order to grasp interpretations of unemployment from the point of view of the people who actually live through it, to understand the meanings it holds for them and to seek explanations for their subsequent behaviour. The overall sample was subdivided into three sub-samples of equivalent size for each of the three cities: Paris, Sao Paulo and Tokyo. In order to study a diversified population while controlling its diversity and avoiding dispersion, four categories defined by specific combinations were targeted: women whose career path had been interrupted by a period of inactivity ('mothers'); workers and employees with families who were experiencing an unplanned hiatus in their career ('workers'); poorly educated
} 
meanings of unemployment are quite heterogeneous: it all boils down neither to the job search nor to expecting to find a job; on the contrary, it removes itself from that institutional definition. Its relationship to employment is tenuous. The diverse ways in which unemployment is experienced follow two of the approaches identified above: projecting oneself into the future and anticipating accessible and rewarding solutions, on the one hand; and developing activities while being unemployed and devising ways of inhabiting that joblessness, on the other.

\section{Anticipating accessible solutions}

The first approach differentiates the ways in which unemployment relates to the possible alternatives and the expectations that give them meaning and colour subjective experiences. On the one hand, unemployment leans towards securing formal and official employment, a job that would hone in on a person's aspirations and focus on their individual behaviour patterns. On the other hand, unemployment is defined by a quest that turns its back on employment, hungers for alternatives and considers withdrawing into an often devalued inactivity. The anticipated solutions may be thought of as definitive (e.g. a stable position, a protective status such as retirement or invalidity) or transitory (e.g. temporary contracts, replacement incomes such as single-parent benefits). Such anticipations rely on fairly elaborate official codifications, depending on the context - retirement is less widespread in Sao Paulo where informal labour is more frequent; a status linked to motherhood or health affords greater protection in the Paris region, etc.

The two extremes may also correspond to prospects that are blurred and not very codified. The spectrum introduces a gradient into the interviews which runs from arguing that securing a job is a guaranteed outcome to tracing precise paths that lead to withdrawal, through projects peppered with uncertainty or ambivalence. Some anticipations bear the stamp of discouragement, a half-hearted job search or the decision simply to give up quietly. Others are oriented towards the margins of salaried employment, largely unregulated forms of working solo and survival activities. Others are also directed towards cursory, barely legible projects, dreams allowing a person to escape from an impossible situation, or mysterious, dramatic occurrences. Whatever they may be, these anticipations represent the experience of

young people seeking occupational integration ('young people'); and members of middle management whose upward mobility had been thrown off course after losing their job ('managers'). Each of the three sub-samples includes the four categories in similar proportions. 
unemployment. They are unemployment. They blur the boundaries between unemployment and employment, making their relationship a tenuous one.

\section{Inhabiting unemployment}

The second approach involves activities developed while being unemployed and the various means of inhabiting that condition. On the one hand, the job search is the main - albeit not necessarily exclusive - activity and gives unemployment its meaning; it is experienced as a deprivation of employment, which calls for focus to be placed on the job search. On the other hand, there is the ability to 'make do', corresponding to activities that procure an income, or offer hopes for one, and are dependent on personal and reciprocal support networks. These two ways of inhabiting unemployment refer to opposite ways of relating to the official definition of unemployment. In the first case, the experience corresponds to its standard definition and to the obligations associated with the status - more usual in countries where systems for servicing, supervising and supporting the unemployed are most developed. In the second case, unemployment causes the regulatory framework to break up, the impact of which is tempered by the creation of systems of redistribution that offer an income or by a codification of labour that reduces the legitimacy of informal activities.

The many ways of experiencing unemployment combine the two models in different forms. The ordeal of finding a job is punctuated by difficulties, uncertainties, disillusionment and failures that may cause a person to flag in their efforts to find a job and undermine their belief in their usefulness. Other types of investment may then balance out these negative aspects in the form of alternative activities such as informal work in a private home, for friends or for an occasional employer. At the same time, a resourceful 'getting along' attitude may give rise to fairly consistent, lucrative and regular source of income, and may coexist alongside the job search. Both activities are often fragile: the job search is vulnerable to the signals received and interpreted - in response to a person's efforts; while the 'getting along' achievements depend on the opportunities close at hand and on the place occupied by that person in the various networks likely to provide such opportunities. The experience of unemployment consists of adjustments and adaptations that combine situations that are clearly distinct on an institutional level, i.e. carrying out a job search and an activity simultaneously. Unemployment has therefore developed into a mixed category.

By extending the analysis of how unemployment is experienced to the international level, the observations made during the French study can be confirmed. The boundaries of unemployment thicken and become hazy, whether seen from the perspective of unemployed 
people's actual activities (oscillating between the job search and 'making do') or of their projections into the future (fluctuating between anticipating a job and withdrawing into inactivity). However, these modifications, which have an impact on the real-life experience of unemployment, remain clandestine or are ignored by the institutions.

\section{Conclusions}

Ultimately, it might be said that unemployment both changes subjectively and remains the same institutionally: its symbolic boundaries are full of holes while its institutional boundaries remain codified; the experience of unemployment stretches out over new areas while the status of unemployment is becoming increasingly restricted. Is unemployment still a shared reference for social representation and action? Unemployment is a distinct category that makes sense in societies where formal labour is sufficiently widespread, and yet it is also a vague concept, despite simultaneously being the result of considerable formal investment (conventions to measure it, surveys to count the unemployed, legal codifications, institutions to manage the populations concerned, systems to monitor individual situations, etc.).

How then can one visualise the boundaries of unemployment? We have brought to light their diversity, each historical period being characterised in terms of the distance between - or proximity to - those boundaries. Two forms of performativity of the border can be distinguished (Gottmann, 1980) that apply the metaphors of 'the door' and 'the bridge' (Simmel, 1988). On the one hand, the border dissociates, separates, divides, selects and partitions. It includes and excludes, and in so doing corresponds to the function of the line, or door. It was this rationale that prevailed when unemployment was first invented in order to break with a non-differentiated treatment of the poor. The contemporary dynamics of the institutional boundaries consist in displacing those barriers, in a move that restricts the domain of unemployment but also preserves that entity, whose boundaries are reaffirmed by being tightened. On the other hand, the border allows one to pass, it crosses, connects, links and conveys. It thus permits circulation and is more like a zone: not a line but a bridge. That is the rationale underlying unemployment as it is experienced: an uncertain condition with unclear limits, for the unemployed are not only jobseekers, they experience and develop a great variety of expectations (unemployment, inactivity and all possible forms of accessible work). The dynamics of symbolic boundaries consist in exploring and extending the border zones.

Two autonomous, dynamic processes thus coexist on the boundaries of unemployment. Uniting them does not lead to confrontation, conflict or contradictions, for they unfold on 
different levels and are served by unequal capacities to express the realities of the world. Unemployment therefore remains immutable, or rather tightens around its normative core, while, at the same time, a growing number of real-life experiences are taking place further and further from that core. One might well wonder up to what point those contradictory tendencies can coexist without challenging the very category of unemployment.

\section{References}

Abbott, Andrew. 'Things of boundaries.' Social Research 62, no. 4 (1995): 857-82.

Angeloff, Tania. 'Des hommes malades du chômage? Genre et (ré-)assignation identitaire au Royaume-Uni.' Travail et Emploi, no. 128 (2011): 69-82.

Bakke, E. Wight. Citizens without Work: A Study of the Effects of Unemployment upon the Worker's Social Relations and Practices, New Haven: Yale University Press, 1940.

Barbier, Jean-Claude, Gautié, Jérôme. Les politiques de l'emploi en Europe et aux États-Unis, Paris: Presses Universitaires de France, 1998.

Barbier, Jean-Claude. 'Le workfare et l'activation de la protection sociale, vingt ans après: beaucoup de bruit pour rien? Contribution à un bilan qui reste à faire.' Lien Social et Politiques, no. 61 (2006): 23-36.

Bartell, Marvin, and Bartell, Riva. 'An Integrative Perspective on the Psychological Response of Women and Men to Unemployment.' Journal of Economic Psychology, no. 6 (1985): 27-49.

Barth, Fredrik. 'Introduction.' Dans Ethnic Groups and Boundaries. The Social Organization of Culture Difference, sous la direction de Fredrik Barth, 1-23. Londres: Allen \& Unwin, 1969.

Castel, Robert. Les métamorphoses de la question sociale. Une chronique du salariat, Paris: Fayard, 1995.

Castel, Robert, Fitoussi, Jean-Paul, Freyssinet, Jacques, Guaino, Henri. Chômage: le cas français. Paris: La Documentation française, 1997.

Clasen, Jochen, Clegg, Daniel. 'Beyond activation: reforming European unemployment protection systems in post-industrial labour markets.' European Societies 8, no. 4 (2006): 527-33.

Daniel, Christine, Tuchszirer, Carole. L'Etat face aux chômeurs. L'indemnisation du chômage de 1884 à nos jours, Paris: Flammarion, 1999.

Degenne, Alain. 'Penser, faire bouger les catégories et leurs frontiers.' Dans Les catégories sociales et leurs frontières, sous la direction de Alain Degenne, Catherine Marry, Sylvie Moulin. Québec: Presses de l'Université Laval, 2005.

Demazière, Didier. Le chômage en crise?, Villeneuve d'Ascq: Presses du septentrion, 1992.

Demazière, Didier. "Chômeurs âgés", chômeurs "trop vieux". Articulation des catégories gestionnaires et interprétatives.' Sociétés Contemporaines, no. 48, (2002): 109-30.

Demazière, Didier. Le chômage. Comment peut-on être chômeur?, Paris: Belin, 2003.

Demazière, Didier. Sociologie des chômeurs, Paris: La Découverte, 2006.

Demazière, Didier. 'Les femmes et le chômage.' SociologieS, (2017). Mis en ligne le 21 février 2017, http://sociologies.revues.org/5966

Demazière, Didier, Guimarães, Nadya, Hirata, Helena, Sugita Kurumi. Être chômeur à Paris, Sao Paulo, Tokyo. Une méthode de comparaison internationale, Paris: Presses de Sciences Po, 2013. 
Demazière, Didier, Foureault, Fabien, Lefrançois, Claire, Vendeur, Aranud. Affronter le chômage. Parcours, expériences, significations, Paris: Centre de Sociologie des Organisations, 2015.

Desrosières, Alain. 'Comment fabriquer un espace de commune mesure? Harmonisation des statistiques et réalisme de leurs usages.' Dans Stratégies de la comparaison international, sous la direction de Michel Lallement, Jan Spurk, 151-66. Paris: CNRS éditions, 2003.

Dubois, Vincent. 'État social actif et contrôle des chômeurs: un tournant rigoriste entre tendances européennes et logiques nationales.' Politique Européenne, no. 21 (2007): 73-95.

Durkheim, Emile, Mauss, Marcel. 'De quelque formes primitives de classification. Contribution à l'étude des représentations collectives.' L'Année Sociologique, no. 6 (1903): 1-72.

Eurofound. Les jeunes et les NEET en Europe. Premiers résultats, Dublin: Fondation Européenne pour l'amélioration des conditions de vie et de travail, 2012.

Evans, Michael. 'Defining the Public, Defining Sociology: Hybrid Science Public Relations and Boundary Work in Early American Sociology.' Public Understanding of Science 18, no. 1 (2009): 5-22.

Eymard-Duvernay, François. 'Principes de justice, chômage et exclusion: approfondissements théoriques.' Dans Les marchés du travail équitables? Approche comparative France/Royaume Uni, sous la direction de Christian Bessy, François Eymard-Duvernay, Guillemette de Larquier, Emmanuelle Marchal, 271-99. Brussels, Peter Lang, 2001.

Freyssinet, Jacques. 'L'indemnisation du chômage en Europe. Entre l'activation des dépenses pour l'emploi et la garantie de minima sociaux.' Pauvreté et exclusion, Paris, La Documentation Française, Conseil d'Analyse Economique, 69-92, 1998.

Gallie, Duncan, Vogler, Carolyn. 'Unemployment and Attitudes to Work.' Dans Social Change and the Experience of Unemployment, sous la direction de Duncan Gallie, Catherine Marsh, Carolyn Vogler, 115-153. Oxford: Oxford University Press, 1994.

Gautié, Jérôme. 'De l'invention du chômage à sa deconstruction.' Genèses 46, no. 1 (2002): 60-76.

Ghesquière, François. 'Précarité du contrat de travail et risque de perte d'emploi en Europe.' Sociologie 5, no. 3 (2014): 271-290.

Gieryn, Thomas. 'Boundary-work and the demarcation of science from non-science: strains and interests in professional ideologies of scientists.' American Sociological Review 48, no. 6 (1983): 781-795.

Gottmann, Jean. 'Les frontières et les marches: cloisonnement et dynamique du monde.' Geography and its Boundaries. In memory of Hans Boesch, Berne: Kummerly \& Frey, (1980): 53-58.

Huyghues-Despointes, Hervé. 'Avoir un emploi et en rechercher un simultanément: types d'itinéraires passant sur la frontière de l'emploi et du chômage.' Revue de l'IRES, no. 35 (2001): 125-153.

Jeanpierre, Laurent. 'Frontière.' Dans Dictionnaire des concepts nomades en sciences humaines, sous la direction de Olivier Christin, 157-169. Paris: Métailié, 2010.

Lamont, Michèle, Fournier, Marcel. Cultivating differences: symbolic boundaries and the making of inequality, Chicago: University of Chicago Press 1992.

Lamont, Michèle. 'Symbolic boundaries: Overview.' International Encyclopedia of the Social and Behavioral Sciences, no. 20 (2001): 15341-46.

Lamont, Michèle, Molnar, Virag. 'The Study of Boundaries in the Social Sciences.' Annual Review of Sociology, no. 28 (2002): 167-195. 
Larquier, Guillemette de. 'Émergence des services publics de placement et marches du travail français et britannique au XXe siècle.' Travail et Emploi, no. 84 (2000): 33-45.

Lefresne, Florence, Tuchszirer, Carole. 'Stratégies d'activation par les activités occasionnelles et normes d'emploi. La situation française confrontée aux expériences belge, danoise, néerlandaise et anglaise.' Travail et Emploi, no. 87 (2001): 47-65.

Lefresne, Florence. 'Les politiques d'emploi et la transformation des normes: une comparaison européenne.' Sociologie du Travail 47, no. 3 (2005): 405-20.

Lefresne, Florence. 'Regard comparatif sur l'indemnisation du chômage: la difficile sécurisation des parcours professionnels.' Chronique Internationale de l'IRES, no. 115 (2008): 3-22.

Lemoine, Matthieu. 'Chômage: débattre de la mesure.' Lettre de l'OFCE, no. 286 (2007).

Luciani, Jean. 'Logique du placement ouvrier au XIXe siècle et construction du marché du travail.' Sociétés Contemporaines, no. 3 (1990): 5-18.

Mansfield, Malcolm, Salais, Robert, Whiteside, Noël. (ed.). Aux sources du chômage, 19801914. Une comparaison interdisciplinaire entre la France et la Grande-Bretagne, Paris: Belin, 1994.

Marchand, Olivier, Thélot, Claude. 'Le nombre des chômeurs.' Économie et Statistique, no. 160 (1983): 29-45.

Marchand, Olivier. 'Statistiques du chômage: les écarts se creusent depuis cinq ans.' Économie et Statistique, no. 249 (1991): 7-14.

Marpsat, Maryse. 'Chômage et profession dans les années trente.' Économie et Statistique, no. 170 (1984): 53-69.

Maruani, Margaret. Les mécomptes du chômage, Paris: Bayard, 2002.

Maruani, Margaret. 'L'emploi féminin à l'ombre du chômage.' Actes de la Recherche en Sciences Sociales, no. 115 (1996): 48-57.

Palier, Bruno. La réforme des retraites, Paris: Presses Universitaires de France, 2003.

Salais, Robert, Baverez, Nicolas, Reynaud, Bénédicte. L'invention du chômage. Histoire et transformation d'une catégorie en France des années 1890 aux années 1980, Paris: Presses Universitaires de France, 1986.

Schnapper, Dominique. L'épreuve du chômage, Paris: Gallimard, 1981.

Serrano, Pascual Amparo. 'Activation regimes in Europe: a clustering exercise.' Dans Reshaping welfare states and activation regimes in Europe, sous la direction de Amparo Serrano Pascual, Lars Magnusson, 275-316. Brussels, Peter Lang, 2007.

Silber, Ilana. 'Space, Fields, Boundaries, the Rise of Spatial Metaphors in Contemporary Sociological Theory.' Social Research 62, no. 2 (1995): 323-55.

Simmel, Georg. 'Le pont et la porte.' Dans La tragédie de la culture, Georg Simmel, 159166. Paris: Payot, 1988 (First Edition, 1909).

Topalov, Christian. 'Invention du chômage et politiques sociales au début du siècle.' Les temps modernes, no. 496-497 (1987): 53-92.

Topalov, Christian. Naissance du chômeur, 1880-1910, Paris: Albin Michel, 1994.

Wierink, Marie. 'La réforme du régime de l'inaptitude au travail.' Chroniques Internationales de l'IRES, no. 76, 2002.

Willmann, Christophe. L'identité juridique du chômeur, Paris: Librairie Générale de Droit et de Jusrisprudence, 1998.

Willmann, Christophe. 'Le chômeur cocontractant.' Droit social, no. 4 (2004): 384-92. 